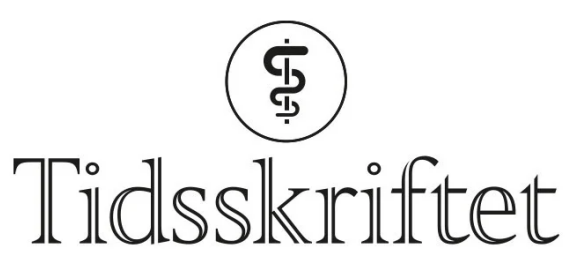

DEN NORSKE LEGEFORENING

\title{
Henvendelser til psykiatrisk legevakt i første fase av covid-19-pandemien
}

KORT RAPPORT

\section{EWA NESS}

ewa.ness@ous-hf.no

Direktørens stab

Oslo universitetssykehus

Hun har bidratt med idé, datainnsamling, dataanalyse, litteratursøk samt utarbeiding, revisjon og godkjenning av manus.

Ewa Ness er spesialist i psykiatri og seniorrådgiver. Hun har bistilling som leder av Psykiatrisk legevakt i Oslo.

Forfatteren har fylt ut ICMJE-skjemaet og oppgir ingen interessekonflikter.

\section{ERIK MYRVANG SALVADOR}

Institutt for militærpsykiatri og stressmestring

Forsvarets sanitet

Han har bidratt med analyser og tolkning av data, litteratursøk, samt utarbeiding, revisjon og godkjenning av manus.

Erik Myrvang Salvador er spesialist i psykiatri, orlogskaptein og

nestkommanderende/fagutviklingsansvarlig psykiater. Han sitter i ledelsen ved Psykiatrisk legevakt.

Forfatteren har fylt ut ICMJE-skjemaet og oppgir ingen interessekonflikter.

\section{ERLEND STRAND GARDSJORD}

Seksjon for tidlig psykosebehandling

Oslo universitetssykehus

Han har bidratt med dataanalyse samt revisjon og godkjenning av manus.

Erlend Strand Gardsjord er ph.d. og konstituert overlege. Han har bistilling ved Psykiatrisk legevakt. Forfatteren har fylt ut ICMJE-skjemaet og oppgir ingen interessekonflikter.

\section{BAKGRUNN}

Vi ønsket å undersøke hvordan covid-19-pandemien i akuttfasen påvirket tilstrømningen av pasienter til Psykiatrisk legevakt i Oslo.

\section{MATERIALE OG METODE}

Alle pasientjournaler fra Psykiatrisk legevakt i Oslo fra og med 13.3.2020 til og med 1.4.2020 ble sammenlignet med pasientjournalene fra samme periode i 2019. Henvendelser ble registrert som covid-19-relaterte i de tilfellene der pasienten henvendte seg med en problemstilling knyttet til dette. 
Psykiatrisk legevakt i Oslo hadde 105 henvendelser i tiden 13.3.2019-1.4.2019 og 63 i samme tidsrom for 2020 (-40 \%). Antall innleggelser var 16 i 2019 og 7 i 2020 (-56\%). Antall covid-19relaterte konsultasjoner var 14/63 (22\%). Det var en nedgang i antall henvendelser for krisereaksjoner, fra 28 i 2019 til 8 i 2020.

FORTOLKNING

Bakgrunnen for reduksjonen i pasienttilstrømningen i akuttfasen av covid-19-pandemien er trolig sammensatt. Vi tror pasienter først og fremst unnlot å oppsøke legevakten på grunn av fare for smitte og ønske om å ikke belaste helsevesenet. Med forbehold om at tallmaterialet er lite, virker ikke økt tilgang på psykiatriske helsetjenester som krever oppmøte, å være indisert i akuttfasen av en pandemi.

\section{HOVEDFUNN}

I perioden 13.3-1.4.2020 ble pasienttilstrømningen til Psykiatrisk legevakt i Oslo redusert med $40 \%$ sammenlignet med samme periode i 2019 .

Det var særlig pasienter med lettere psykiske lidelser som uteble.

14 av 63 pasienter hadde psykiske problemer utløst av covid-19-pandemien, hvorav 7 hadde angst.

En pandemi kan ramme befolkningen både somatisk og psykologisk. $24 \%$ av befolkningen i England rapporterte om angst i forbindelse med svineinfluensaen i 2009 (1) $)$. Vi ønsket å undersøke hvordan covid-19-pandemien i akuttfasen påvirket tilstrømningen av pasienter til Psykiatrisk legevakt i Oslo.

\section{Materiale og metode}

Psykiatrisk legevakt er et poliklinisk akuttilbud i regi av Oslo universitetssykehus, lokalisert ved Legevakten i Oslo sentrum, med åpningstid på kveld og i helger. Tilbudet betjener ca. en million innbyggere i og rundt Oslo. Pasientene trenger ingen henvisning, men blir triagert av sykepleiere i mottaket før vurdering av psykiater eller psykologspesialist.

Vi sammenlignet journaler fra de første 20 dagene etter at den norske regjeringen 12. mars 2020 varslet strenge tiltak på grunn av covid-19-pandemien, med samme periode i 2019 (fra og med 13. mars til og med 1. april). Vi har lest og vurdert alle journalene i det gitte tidsrommet og skjønnsmessig vurdert konsultasjonene ut ifra hvilken problemstilling pasientene presenterte og om problemstillingene endret seg fra 2019 til 2020.

Henvendelser ble registrert som covid-19-relaterte i de tilfellene der pasienten henvendte seg med en problemstilling knyttet til dette. Det brukes ICD-10-diagnoser, men mange pasienter får ikke en spesifikk diagnose fordi det ikke foreligger nok opplysninger etter én konsultasjon. Vi har derfor laget en sykdomsinndeling basert på problemstillingen som førte til henvendelsen. Under grupperingen «kriser» ligger konflikt eller brudd i nær relasjon, arbeidskonflikter eller sorgreaksjon i forbindelse med dødsfall. Studien er lagt frem for personvernombudet ved Oslo universitetssykehus, som konkluderte med at studien kunne gjennomføres uten en formell vurdering.

\section{Resultater}


Sammenlignet med samme periode i 2019 falt antall henvendelser til Psykiatrisk legevakt fra 105 i 2019 til 63 i 2020 de 20 første dagene av covid-19-nedstengningen. Dette tilsvarer en reduksjon på 40\%. Det var også en reduksjon i antall psykiatriske innleggelser, fra 16 til 7 . Antallet tvangsinnleggelser var relativt stabilt (syv i 2019, seks i 2020).

14/63 (22\%) konsultasjoner omhandlet covid-19-relaterte problemstillinger. Syv hadde fått økende plager med angst og uro i forbindelse med isolasjon og på grunn av bekymring for smitte. Blant de øvrige syv som ble vurdert som covid-19-relaterte, var årsaken til kontakt av ulik karakter, som fortvilelse over at de ikke fikk den samme oppfølgingen i spesialisthelsetjenesten som tidligere, ensomhet, økende tvangstanker, økonomiske bekymringer, konflikt og psykotisk gjennombrudd. Ingen av pasientene hadde covid-19 eller hadde vært i kontakt med personer som hadde fått påvist sykdommen.

Tabell 1 viser fordeling av kontaktårsak/problemstilling i de to tidsperiodene. Mens antallet pasienter med rusproblemer og personlighetsforstyrrelser stort sett var uendret, så vi en tydelig nedgang i antall konsultasjoner grunnet livskriser og depresjon. Vi observerte også en nedgang $\mathrm{i}$ antall konsultasjoner for psykose, men denne reduksjonen var mindre tydelig. Antall konsultasjoner med selvmordsproblematikk eller selvskading var også redusert, fra 38/105 (36\%) i 2019 til 15/63 (24\%) i 2020.

\section{Tabell 1}

Psykiatriske problemstillinger ved henvendelse til Psykiatrisk legevakt i Oslo i perioden 13.3-1.4. i 2019 og 2020 (antall).

\begin{tabular}{|c|c|c|}
\hline Psykiatriske problemstillinger & $\begin{array}{l}\text { Tidsperiode } \\
\text { 13.3.-1.4.2019 }\end{array}$ & $\begin{array}{l}\text { Tidsperiode } \\
\text { 13.3.-1.4.2020 }\end{array}$ \\
\hline Krisereaksjon & 28 & 8 \\
\hline Rus & 22 & 20 \\
\hline Psykoselidelser (inkludert bipolar lidelse) & 18 & 12 \\
\hline Depresjon & 11 & 2 \\
\hline $\begin{array}{l}\text { Angst (inkludert posttraumatisk } \\
\text { stresslidelse og tvangslidelse (OCD)) }\end{array}$ & 10 & 8 \\
\hline Personlighetsforstyrrelser & 7 & 6 \\
\hline Uspesifisert psykisk lidelse & 7 & 7 \\
\hline Annet & 2 & 0 \\
\hline Totalt & 105 & 63 \\
\hline
\end{tabular}

\section{Diskusjon}

Antallet pasienter som oppsøkte Psykiatrisk legevakt i Oslo fra og med 13. mars til og med 1.april, var redusert med $40 \%$ sammenlignet med samme periode i 2019. Antall konsultasjoner for rusproblemer og personlighetsforstyrrelser var lite endret, mens kriseog depresjonsutløste konsultasjoner gikk tydelig ned. Antallet tvangsinnleggelser var stabilt, mens frivillige innleggelser sank fra ni i 2019 til én i 2020. Vi tror dette kan henge sammen med nedgangen i konsultasjoner grunnet livskriser og depresjon. 
I Kina har man undersøkt psykiske reaksjoner i den første fasen av covid-19-utbruddet. Her fant man at over halvparten av respondentene i en spørreundersøkelse hadde moderate til alvorlige psykiske plager, der angst var det vanligste (1). Vi kan ikke direkte sammenligne oss med forholdene i Kina, men 7 av 14 med covid-19-relaterte plager hadde angst som problemstilling også hos oss.

Akuttmottaket ved St. Olavs hospital meldte om 39 \% reduksjon i pasienttilstrømningen i uke 12 sammenlignet med tilsvarende uke året før (므). Det er interessant at tallene deres og våre er så like. Befolkningen oppfatter sannsynligvis helsevesenet som et smittefarlig sted, og de tar rådene om sosial distansering på alvor. Synet av personell i beskyttelsesutstyr som tar prøver utenfor sykehuset eller i telt, bidrar til dette inntrykket. Folk kan ha trodd at helsetjenesten var overbelastet og av den grunn ha unngått å oppsøke legevakten. Dette har vi ikke data for, og årsaker til endringer i hjelpesøkende atferd under en pandemi bør undersøkes nærmere. Vi kan heller ikke utelukke at reduksjonen i antall frivillige innleggelser kan ha blitt påvirket av en høyere terskel for å legge inn pasienter den første perioden av pandemien.

En oversiktsartikkel viser at karantene på kort sikt fører til depressive plager, angst, sinne og bekymring (3). Dette er normale reaksjoner på karantene. Informasjon om normale psykologiske krisereaksjoner ved belastninger er derfor viktig for befolkningen og kan forhindre at disse tolkes som sykdom. God informasjon er et tiltak som også kan virke beskyttende mot varige plager og sykdomsfølelse (4).

I boken Psychology of Pandemics (5) skriver Taylor at det er undervurdert hvor stor psykologisk virkning en pandemi har på befolkningen. Ikke bare under pandemien, men også i kjølvannet av den, må man forvente krisereaksjoner og depresjoner i forbindelse med dødsfall, tap av arbeid og inntekt, familiekonflikter, isolasjon og flytting.

Styrken i denne studien er at tallene stammer fra en uselektert legevaktsetting som betjener en relativt stor befolkning, noe som øker validiteten. Svakheten er at tallmaterialet er lite. Dette gjør det vanskelig å gjøre pålitelige statistiske analyser.

\section{Konklusjon}

Med forbehold om at vi har små tall over en kort periode, kan det se ut som økt tilgang på psykiatriske helsetjenester som krever oppmøte, ikke er indisert i akuttfasen av en pandemi. Dette funnet er interessant for akuttjenestene innen psykisk helsevern og for legevakter.

Artikkelen er fagfellevurdert.

\section{LITTERATUR}

1. Wang C, Pan R, Wan X et al. Immediate psychological response and associated factors during the initial stage of the 2019 coronavirus disease (Covid-19) epidemic among the general population in China. Int J Environ Res Public Health 2020; 17: 1729. [CrossRef]

2. Bjørnsen LP, Næss-Pleym LE, Dale J et al. Pasienttilstrømming i et akuttmottak i påvente av covid-19pandemien. Tidsskr Nor Legeforen 2020; 140. doi: 10.4045/tidsskr.20.0277. [PubMed][CrossRef]

3. Brooks SK, Webster RK, Smith LE et al. The psychological impact of quarantine and how to reduce it: rapid review of the evidence. Lancet 2020; 395: 912-20. [PubMed][CrossRef]

4. Iversen AC, Fear NT, Ehlers A et al. Risk factors for post-traumatic stress disorder among UK Armed Forces personnel. Psychol Med 2008;38: 511-22. [PubMed][CrossRef] 
5. Taylor S. Psychological reaction to pandemics. I: The Psychology of Pandemics: Preparing for the Next Global Outbreak of Infectious Disease. Newcastle upon Tyne: Cambridge Scholars Publishing, 2019 .

Publisert: 13. august 2020. Tidsskr Nor Legeforen. DOI: 10.4045/tidsskr.20.0388

Mottatt 28.4.2020, første revisjon innsendt 8.6.2020, godkjent 2.7.2020.

Publisert under åpen tilgang CC BY-ND. Lastet ned fra tidsskriftet.no 26. april 2023. 